\title{
A COMPREHENSIVE FRAMEWORK PLANNING FOR RECONSTRUCTION AND DEVELOPMENT OF THE KURDISTAN REGION IRAQ
}

\author{
Othman Karim Mohammed \\ Sulaimanyia Technical College \\ (Received:19/6/2012 ; Accepted:27/9/2012)
}

\begin{abstract}
The concept of the case study "comprehensive framework planning" is crucial to consider it encompasses a number of important issues relevant to rebuild and develop the Iraqi Kurdistan- especially the countryside- after miss-failure of the regional government to master the reconstruction and development problem, of which three major interconnected issues that of integration, coordination and sustainable development. It begins to produce connections of integrated governance, spatial integration, and sustainability to those of very local- and regional-based needs. Accordingly, it specifies the root causes the entire accumulated-chronically problems in both rural and urban areas and worked out the related solutions in form of a "frame work planning", within which the interconnected sphere, of Agriculture, industry, environment impacts, housing and related infrastructures integrated.

Then the study assumes that most of the reasons that have led to miss-failure of the regional governments lie in the miss-definition the problem itself that results in the sporadic, disintegrated, disjointed manner of planning actions of institutions that involved directly or indirectly in rehabilitation and development affair of the region. In addition to this, the development problem is still seeing to be as if the provision of housing only.
\end{abstract}

Keywords: Comprehensive framework planning, Industry, Coordination and Sustainable development.

\section{BRIEF INTRODUCTION}

The Kurdistan region/Iraq, as the name indicates, follows a federative system. It encompasses three so called Parezgas (Muhafazat) Arbil, Sulaymaniah, , and Dahuk. It covers a continuous land mass of nearly 406 thousands square kilometers. The total 
population of the Region in 2003 was 3.910. 329, in 2008 were 4.382 .790 in 2009 was 4.698.790" and the current population is estimated to be ca. 5 million inhabitants, the bulk of which (ca. 3 Millions) living in the three mentioned big cities. Thus, the average physiological bearing capacity or demographic density is 10 inhabitants per square kilometers. The statistics data for 2006-2007 indicate that \%77.6 of the total population living in cities whereas $\% 22.4$ of them is rural inhabitants (see tables 1 and 2). The population growth is estimated to be $3 \%$. Over $60 \%$ are younger than 20 years of age. City planning, Transport, water supply, drainage, have traditionally been regarded as the municipal function. There are also strong disparities among municipalities either in terms of territorial extension, population or in the financial and administrative resources by maintain their services. The chief regional institutions with an interest in rehabilitation are the ministry of reconstruction, Investment board, and partly the ministry of transport and ministry of planning with control over financial allocations for development. According to Data's obtained from department of statistics in Sulaimaniyah "2527 villages, 426 Nahias and 5 Qaza's " were destroyed during the period of wars.

Nowadays - after 20 years of establishing the regional government- hardly a destroyed village among 2527 destroyed villages is rebuild or repopulated at an acceptable level.

Table 2 shows clearly that the increase in population in the three major cities given, is ca. 3 times higher than in urban regions, especially in the year 2010. Note that the development by 2011 is higher for which population data is still not available.

Table 3 indicates the unemployment problematic -especially in the rural areas which forced the population, especially the youth to immigrate to the urban areas, especially into three major cities, where the quantity of workplaces is far below the demand side (compare the section: problem definition).

\section{RESEARCH PROBLEM}

\section{Problem definition}

Rehabilitation problem in Iraqi Kurdistan is a complex multidimensional problem, which can be classified into three problem groups as follows:

A. In the countryside as a whole, the scattered- settlements pattern represent many folded problems both in terms of economic development and the availability of services due to the fact that the planned development of all regional government in Kurdistan region have been concentrated almost on the three big cities (Arbil, Dahuk and Sulaimaniyah) whereas the destroyed country side and rural areas - inclusive local municipalities so 
called Qasa's and Nahia's, have been given little attention. As the result the urban-rural unbalance, worsened dramatically leading to exacerbate the situation in terms of over crowding, congestion, housing shortage, luck of infrastructure, and congestion of traffic roads, etc.

B. Rural-urban migration: $\left({ }^{*}\right)$ The present socio-economical and situation in countryside provides no employment or other income generating possibilities, except a few agricultural or vie-stock based ones -far bellow the level of demand-, so people intend to migrate to the urban centers (especially to the three major big cities Arbil, Sulaimaniyah, and Dahok) in search, not only for employment opportunities, but also to access to higher education, better housing and other social services and facilities that couldn't find in their native home villages. Following an attempt will be made to analyze the problem of internal migration (see Figur1).

C. The network of urban municipalities, especially between the rural cities on the one side, and between these and the villages and among the villages themselves is primitive and incomplete. Since both of the urban-rural and rural-rural network is deficient and poor, so the provision of workplaces as well as services such as hospitals, secondary schools, cultural facilities almost of low level, and also difficult to improve in areas without urban centers.

\section{RESEARCH TARGETS}

The target of the research is two folded as follows:

i. Revealing the interdependences - from the view point of planning- between the agricultural,- industrial and settlement development planning and the overall land development planning on a sustainably basis in the study area.

ii. Coordination and integration of all planning measures related to the sectors mentioned within a comprehensive framework plan with the aim achieving an urban-rural balance, without burdening the natural environment.

\section{MATERIALS AND METHODS}

A relative considerable part of materials used to conduct this study is related to the long year lasted experiences, with the problematic of the study area, of the researcher himself. As a

)$^{*}$ ( The Phenomenon of rural-urban migration is almost an international Phenomenon. It occurs in almost all countries in the world but with differences in quantities, intensities and the driving forces. 
son of a farmer he has lived and worked for more than 20 years in the countryside in the study area. In addition to this, his academic field, since 12 years, supported by his intensive observations and his growing interest to the problematic of the land development increases the broadness of his vision and the bulk of the materials needed to accomplish this task. Thus the study represents a case study and the methods are mostly descriptive-analysis.

\section{THEORETICAL AND PLANNING BACKGROUNDS}

The theoretical background of the research based on two logically connected concepts, namely the (1) social model [1] and (2) the people-land model, concepts. While the social model concentrated on "planning for equality"[2] regarding to provision of basic needs for all population groups in the region (not only rural but urban sectors too), the population-land or/ Man-Land-model focuses on analyzing of the relationship between the "Man and "Land" (i.e. land as a habitation, object for food-stuff production and for living and recreation purposes, etc.) From economically and planning's standing points, both the land and population appear on both supply and demand sides. Thus, "Man" and "Land" are representing two opposing antagonistic component-forces, on the planning sphere that must brought together in harmony. While the population-component is tending to increase permanently, in contrast to it, the availability of land (land-component) is a fix a mount that can't be increased or expanded according to the raise in population or to adjust it to their basic needs; even though it diminishes both quantative and qualitative (diversification, pollution etc.).With other words, we have always a fewer land available for always more and more people (see fig 2). To orientate development in such away that each settlement (or village) of the countryside as, an integrated unit, can take part in the national division of productions factors on the basis of local natural resources and characteristics, it is necessary to identify the local and regional potentials to assess the local and regional development potentials. But, owing to the fact that natural resources don't distributed evenly over the natural environment so this has a considerable effect on both the choice of settlement location as well on its future expansion (see land classification in section planning measurements). With other words; there is a considerable difference between localities with regard to their physiological bearing capacity or utilization for human needs and purposes. Through adequate planning measurements such as population redirection, redistribution, special measurements according to the prevailing situation coming in question. Fig. 3 explaining this issue by discussing the way's how to 
achieve the equilibriums state also on the natural land (compared with the achieving the equilibriums state by a building structure).

\section{PLANNING MEASUREMENTS AND DISCUSSIONS:}

Planning measurements necessitates looking at the equilibriums state also from the view point of the different geographical realities of the study area which reflected into formulating a different planning measurement to achieve the equilibrium. It is therefore important here to attend this thematic -the land topology-, so to say giving a "suitability certificate" to each zone or land-type, to indicate its potentials for population -needs and planning purposes. Accordingly, all the defined measurements, such as the regional integration plans, rural development plan, definition of framework planning, and the resulting recommendations that follow are based on this land-topology. For the purpose of this study, Kurdistan region can be simply divided or classified into three main land-categories [3, p. 43] and many sub-regions* as follows: (I) The low-land (II) The mountainous region and (III) the transition zone between the two formers. Thus the achievement of the spatial balance depends mainly on the successfulness (1) of the land-use with regard to characteristics of each land category, and (2) the extend of the combined effect of land-uses between the three land categories, with respect to population distribution and resource availability. A glance at fig. 4 reveals into some extend the "suitability index" of the land for human needs and planning purposes, especially the uses among the three main planning and economic spheres or sectors, namely agriculture, industry and the settlement planning or housing - including the network services. With regard to the interdependences between these economical sectors mentioned, the creations of a frame work plan and its basic parts can be represented as the three interrelated and integrated concepts program types (see also fig.5):

I- A regional wide -livelihood development program,

II- Elaboration of a community development and services delivery program and

III- Elaboration of a Kurdistan-wide decent-housing program.

In the following figures (5-9) the elements forming each of these programs are presented in details. Yet there are still two important notes remain to be given: (1) the agriculture and related fields, such as horticulture, gardening, and poultry, take a key role, since it provides a solid base to the industrialization processes described. Here a special attention should be given to the merging issues of farmers. The present situation with small available agricultural

\footnotetext{
* Sub-regions are relative small areas-compared to the three main regions mentioned- that have the characteristics of one of the three named Land-class sprawled in form of parcels within it.
} 
land - especially in land-type 3 and 2 can't be cultivated in an economical way. It is therefore a quasi- collectivization in agriculture land can be profitable that enable to working on large land areas with modern machinery that produce sufficient agricultural row materials for either consuming and for future industries. (2) With regard to the issue of settlements; this enjoys unquestionable priority, since their development, are rising in the areas of economic policy and social policy, with equal force. Besides the housing issue, the development of the most needed local and regional services takes a prominence place. Their need emerges, in part, directly from industrial development, as the various rising industries demanded labor of various skills at various grades, which, in turn, will be fulfilled by the extension and improvement of the educational system. Furthermore, with the increase of female labor, a growing proportion of traditional household functions will be industrialized in the form of various public services like child-care, care for the elderly, shopping and catering services, Finally, especially as living standards are going to rise, the improvement of the accessibility to and the quality of medical, cultural, commercial, etc. services would be an articulated public need. The recognition of these needs is led to an increase of resources for settlements development from the state budget.

A glance at table 4 shows that the three main branches pertinent to this research, namely Agriculture, industry, and tourism are far below the necessary level, which justify and give enough evidence to the study presented. In addition to this, the establishments are not related to each other and not coordinated in a correct manner (see table 5). With regard to the items (Municipalities and Working \& reconstruction by $26.6 \%$ and $13.8 \%$ respectively) both items considered to be the most supportive base to former branches. But, owing to the disintegrative manner of projects and allocated funds and the concentration of housing issues in cities on the one hand and the luck of institutional arrangement on the other hand fail the success the end result is the de-facto stated in this study.

Table 5 shows unrealistic and surprised vision; then while the number of food industries is 69 the consumer market will collapse within 24 hours, if the transition routes between Iraqi Kurdistan and the neighbor lades like (Iran, Syria and Turkey) is closed.

\section{CONCLUSION}

The study claims to have provided an adequate assessment of the accumulated problem facing the Iraqi Kurdistan. So it is possible to draw some conclusion points as follows: 
Firstly, the emphasis placed on agricultural and industrial development and also on housing measures as a means of solving the current problem of spatial planning and organization to combat both rural and urban problems. Here the co-operation actions of the related ministries are also reflected. The success of these instructions is proofed through developing a "Landstructure-analogy" scheme, relating to the physiologically bearing capacity (see fig. 3).

Secondly, the study has worked out real planning possibilities that ensure providing the eleven basic needs for the population and the integration planning measures of all the institutions coming in question at the same time. These basic needs are: Water, power, food, medical services, livelihood, industries for manufacturing for domestic market, education; cultural and technology, ecological balance, shelter (housing and land use), mobility (roads, transportation, and communication), sports and recreation" [5 p.283]. The provision of these basic needs is the function of the type of land uses, as explained through land typology and planning measurements, which explains:

- The availability of natural resources (resources for the development of industries, agriculture and recreation) and manpower resources

- The type and availability of connections to the national and regional transport and other infrastructural networks and other services and

- The availability of local building material

At the last it remains to hope that the emerge of a new institutional- and administrative era (since 1991 in Iraqi Kurdisatan and since 2003 in Iraq as a whole) that has sited up a new administrative institutions, and bring about an adequate budget, all these sufficient enough to develop the land in general and reconstruct the destroyed country side in special, as presented in this case study.

\section{REFERENCES}

1. Town and Country Planning Association 17 Carlton House Terrac applying inclusive design principles to eco-town development.Eco-towns Inclusive Design Worksheet, Advise to promoters and planners, May 2009.

2. Planning for Equality and Diversity in London, 2009.

3. Othman-Zamdar Karim Mohammed, Ansaetze zu einer Ressourcenorientierten raumordnung mit angepasster siedlungsplanung und sonnen gerechter gebaeude 
plannung im Irak, dargesteelt in den muhafazat Kerkuk, Arbil and Sulaimanyiah. Dissertation Technical University Berlin, 1991.

4. G. Tyler Miller, JR. President, Earth education and Research. Adjunct professor of Human Ecology: Living in the environment, Principles, Connections and solutions, 2004.

5. National Human Settlements Institutional Arrangements, selected Case study United Nations center for Human Settlements (Habitat) Nairobi, 1997.

6. Journal of Koye University, No. 20, September, 2011.

7. Albonico and Sachs (2002) Development plan for the east Bank and Far East in Alexandra.

8. website/ http://www.pratt.edu/city_regional_planning\#.

Table (1): Population distribution by rural and urban for the three main cities (source Ministry of planning, Kurdistan regional government, demographical and economical survey).

\begin{tabular}{|c|c|c|c|}
\hline & Governorate & Qaza,s and Nahias $^{1}$ & Villages \\
\hline Arbil & 50.9 & 30.7 & 18.4 \\
\hline Dahuk & 25.9 & 46.5 & 27.6 \\
\hline Sulaimaniyah & 33.4 & 45.4 & 21.2 \\
\hline Total/ average & 36.7 & 40.9 & 22.4 \\
\hline
\end{tabular}

1 Qaza,s and Nahia,s are Arabic words, mean administrative units with own municipalities smaller than governorate. 


\section{A COMPREHENSIVE FRAMEWORK PLANNING FOR RECONSTRUCTION AND DEVELOPMENT OF THE KURDISTAN REGION IRAQ}

Table (2): Population development in Kurdistan Region Iraq by urban and rural for three main cities, between 1965-2010 (Source: statistical officials in Sulaimaniyah)

Sulaimaniah

Arbil

Dahuk

\begin{tabular}{|c|c|c|c|c|c|c|}
\hline Year & Urban & Rural & Urban & Rural & Urban & Rural \\
\hline 1965 & 272036 & 127732 & 134151 & 222142 & 51751 & 94083 \\
\hline 1977 & 344859 & 298343 & 139175 & 226806 & 53727 & 97905 \\
\hline 1987 & 680857 & 270866 & 596118 & 174321 & 218710 & 74594 \\
\hline 2010 & 1526540 & 270968 & 627003 & 175550 & 227272 & 75832 \\
\hline
\end{tabular}

Table (3) ${ }^{2}$ : Unemployment rates by urban and rural for three main cities given. (Source: Ministry of planning, Kurdistan regional government, demographical and economical survey)

\begin{tabular}{|c|c|c|c|c|}
\hline & Center & Surrounding & Villlage & Average \\
\hline Arbil & 7.24 & 16.3 & 23.9 & 15.81 \\
\hline Sulaimaniyah & 10.45 & 13.36 & 11.26 & 16.69 \\
\hline Dahuk & 14.26 & 18.2 & 17.51 & 16.65 \\
\hline Average/ total & 16.65 & 15.95 & 17.56 & 16.38 \\
\hline
\end{tabular}

Table (4): Allocations of funds for sectors listed by percentage and year for the whole region (source: Department of statistics / Sulaimaniyah).

\begin{tabular}{|c|c|}
\hline sectors & percentage \\
\hline Agriculture\& irrigation & $2.2 \%$ \\
\hline Social & $0.7 \%$ \\
\hline Communication. \& transportation & $0.7 \%$ \\
\hline Municipalities & $26.6 \%$ \\
\hline Culture & $0.7 \%$ \\
\hline electricity & $8.6 \%$ \\
\hline tourism & $0.8 \%$ \\
\hline finance & $0.8 \%$ \\
\hline industry & $0.1 \%$ \\
\hline health & $7.4 \%$ \\
\hline Working\& reconstruction & $13.8 \%$ \\
\hline Water resources & $0.6 \%$ \\
\hline education & $4.0 \%$ \\
\hline
\end{tabular}

${ }^{2}$ Figures in the table are corrected by researcher owing to a slight miscalculations occurs. 
Table (5): Number and name of industry enterprises by percentage up to 2011 (source:

Department of statistics / Sulaimaniyah).

\begin{tabular}{|c|c|c|}
\hline Sectors & Number & percentage \\
\hline Food industries & 69 & $24 \%$ \\
\hline Building industry & 190 & $65 \%$ \\
\hline Plastic industries & 14 & $5 \%$ \\
\hline Metal industry & 5 & $2 \%$ \\
\hline Mixed industry (others) & 14 & $5 \%$ \\
\hline Total & 292 & $100 \%$ \\
\hline
\end{tabular}

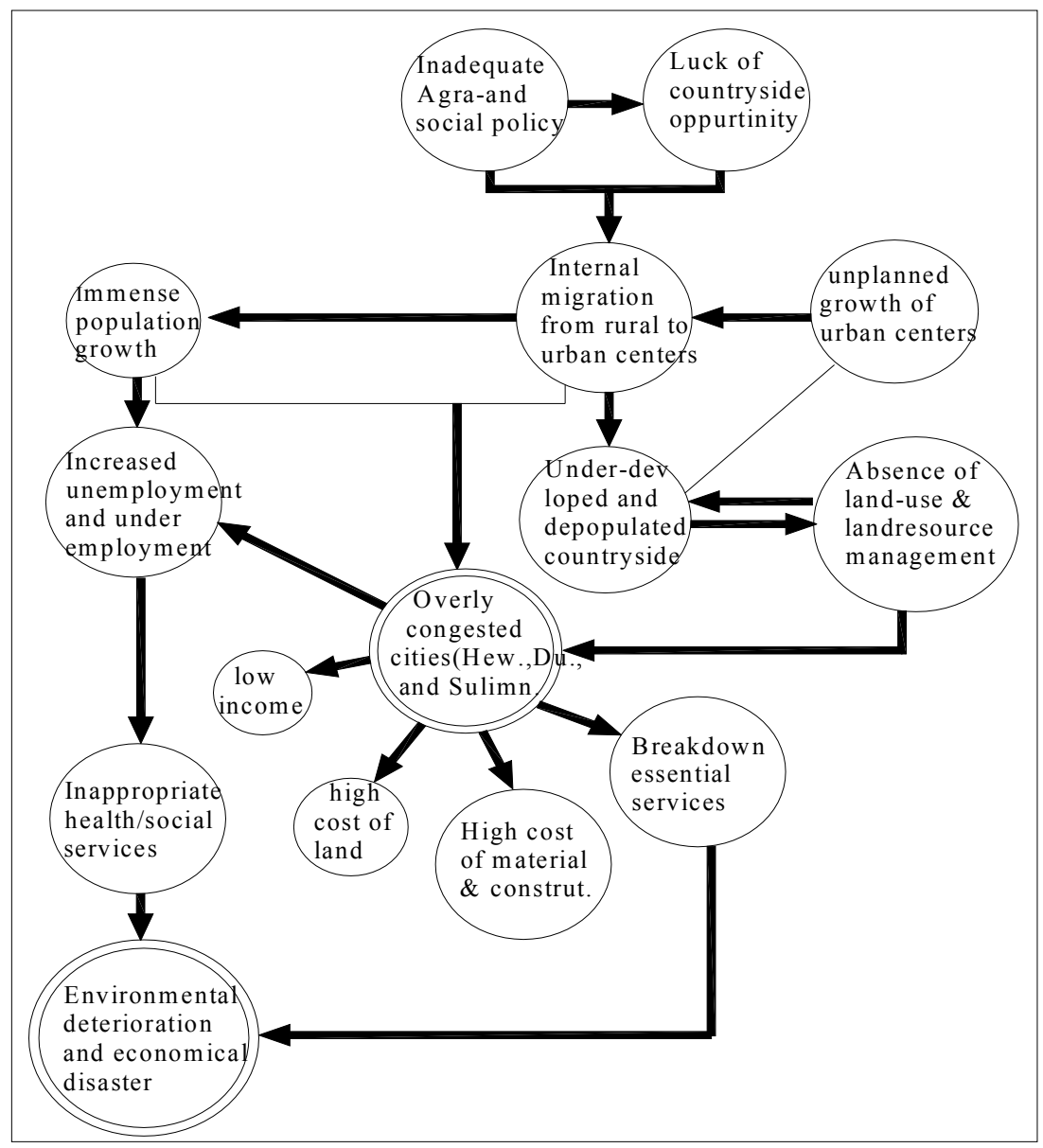

Fig. (1): Flow diagram showing major problem component that causes high out migration from the country side and high concentration in the three main Cities (Arbil,Sulaimania and Dahok) Source: adopted with the necessary altering from [5, P.277]. 


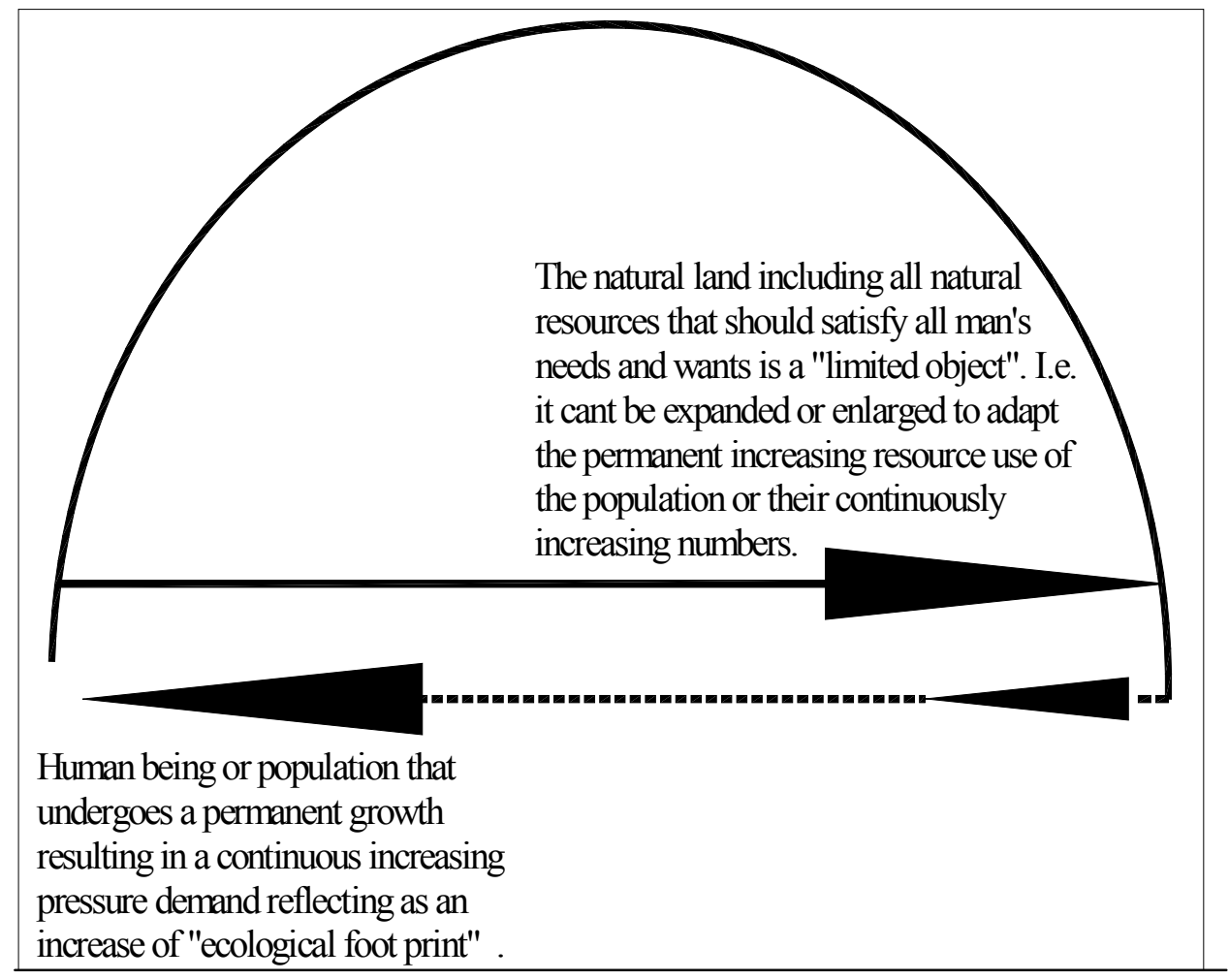

Fig.(2): Human-land relationships: Explaining the unavoidable conflicts between "Man" from one side and the natural land from the other. (Source: Researcher).

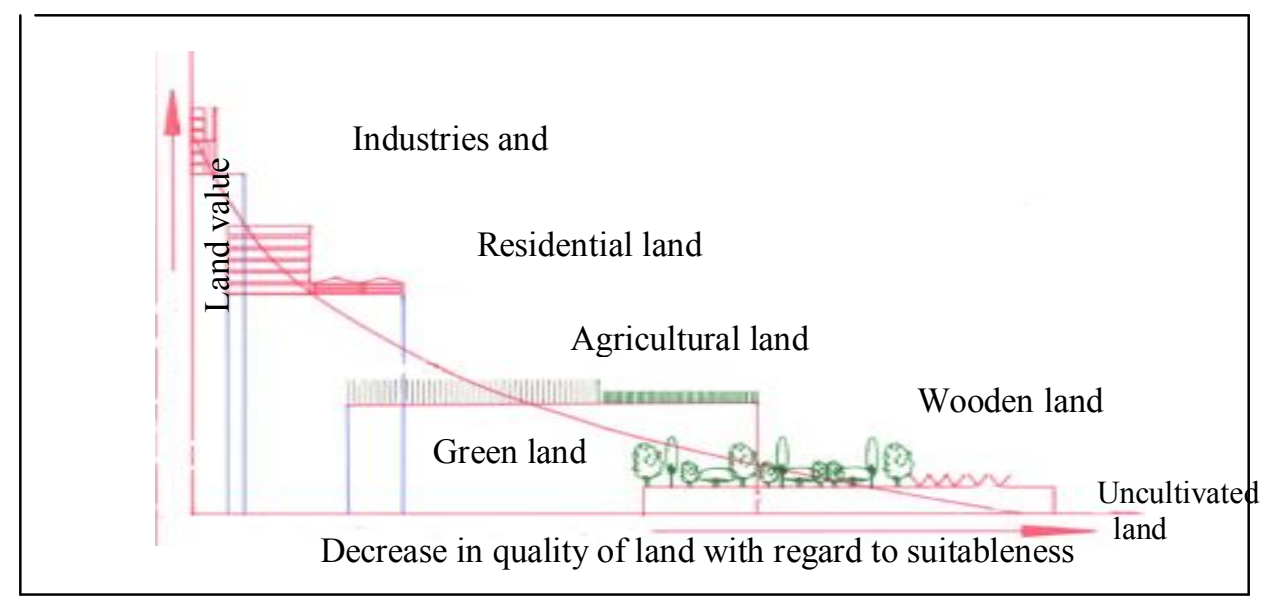

Fig.(3) : Land values and its suitability's for human needs and purposes (According to Barlowe, Source : Reference 3). 


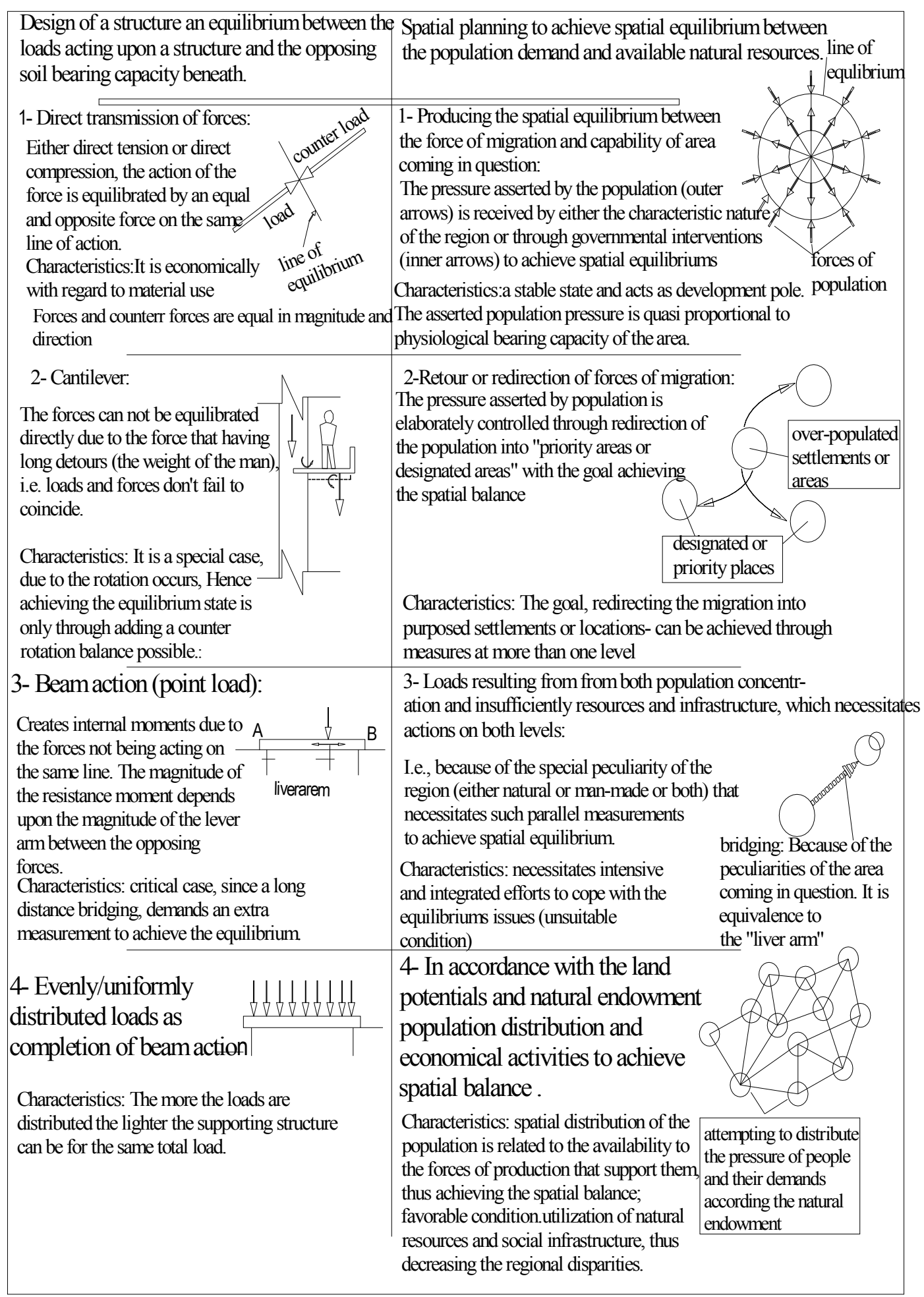

Fig.(4): Force/ Load - population and land analogy: It explains the inteded equilibrium's process on the natural land compared with such by a solid(Source: developed by researcher). 


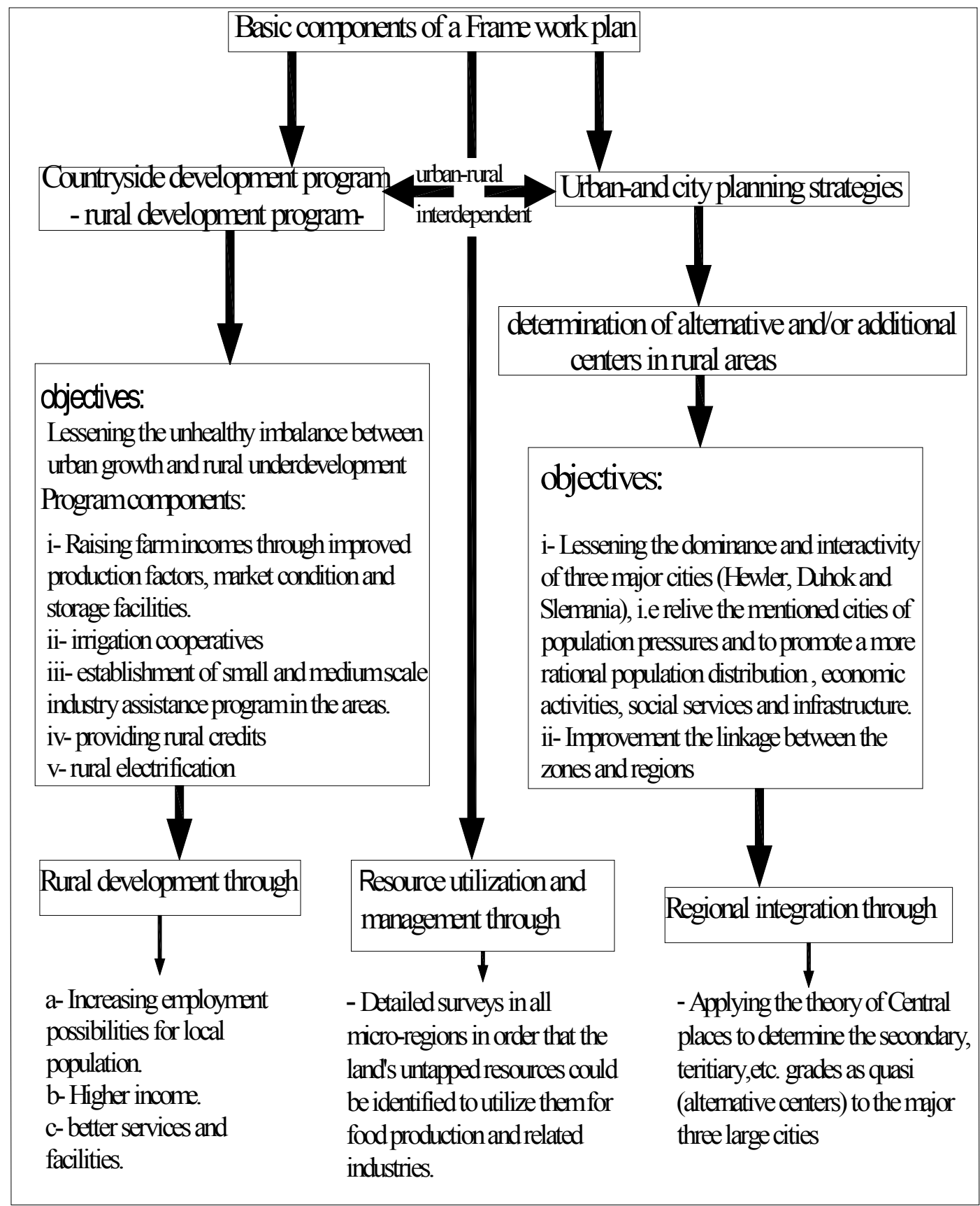

Fig.(5): Basic componenets of the comprehensive frame-work planning. It is considered to be the real planning consequences from the phnomenon high out migration from the countryside and high concentration in the three major cities, see also Fig. 1 (Arbil, Sulaimania and Dahok). (Source: Researcher) 
The creation of a regional-wide livelihood development program follows the principle of the spatial allocation of forces of production or resource availability. In this regard the following three development program-sectors, as the consequence of the framework-plan (fig 5), are coming in question:

I- mainly an agrar/industry-cum-livelyhood program for producing and providing domestic products to a level of self-sufficiency, (see fig.7)

II- mainly industry-cum-liveliyhood development programs strategy (see fig. 8)

III- mainly settlement based program, as quasi housing cum-liveliyhood development program (see fig. 9)

All program parts are aiming to mobilize the local resources and are suited to the geographical realities, natural resources and manpower of the regions.

programe types:
\begin{tabular}{|l|l|l|}
\hline - Development of material \\
- Light industries \\
-Waste utilization \\
-Services, such as market \\
development \\
- Housing program
\end{tabular}
$\begin{aligned} & \text { - Primary projects: concerning with raw materials, } \\
& \text { production and farm-based activities. }\end{aligned}$
$\begin{aligned} & \text { - Secondary projects: final and intermediate } \\
& \text { processing of raw materials such as feed mil, small } \\
& \text { and medium scale manufacturing. }\end{aligned}$
$\begin{aligned} & \text {-Tertiary projects: include those which should support } \\
& \text { primary and secondary projects, such as transport } \\
& \text { facilities, trading services, warehousing and silos }\end{aligned}$

Fig.(6): Basic componenets of livelyhood- and development plan.(Source reraseracher). 
Development of the national livelihood program

Deod development program

The creation of livelihood development program on the agrarian base follows the principles of spatial allocation of forces of the production. The aim is to promote income generating opportunities opportunities,especially in the priority areas designated as special centers and sub-centers

The designation of the priority areas - identified as under-developed and depopulated areas - based on the (theory of central places of Christaeler) most of which located in(sub-zone 3) mentioned in land topology. This program focuses on two major areas-based livelily program components as follows: aFrontier areas or regions that needs a multi-and inter-sectoral measurements, and b- Areas predestinated and designated as tourist regions.

component 1

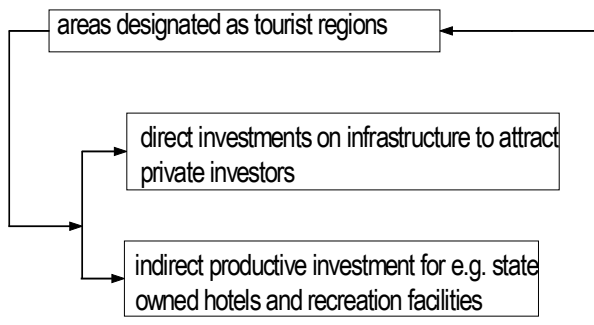

component 2 maily frontier regions multi-and inter-sectoral measurements

combination of urban/rural infrastructure incentives and support of traditional in-bond hand skills

II- Industry cum-livelihood program/ industrial decentralization concept

Industrial decentralization concept: In the economic and regional planning sphere kurdistan's industrial development policy must first be focused on the production of consumer goods with urgent-need character for the domestic market. In these sense the provision of food industries based on agricultural raw materials get the first priority. Hence and in this way a true interdependencies between Agra and industry is produced. The location of such industries and plants has also to follow the decentralization principles and outside the three main cities.In this sense industrial decentralization acts as a effective tool for upgrading of underdeveloped and depopulated areas. This policy include two basic approaches

\begin{tabular}{|l|l|l|}
\hline $\begin{array}{l}\text { Fiscally or public } \\
\text { based approach }\end{array}$ \\
of operation \\
oil and natural gas to the \\
ansumers and industries in the \\
priority areas
\end{tabular}

Fig.(7): Planning measurements- Agra-Industry-Interdependences-: Showing the principles of spatial allocation of forces of production: (Source Reasearcher). 


\section{A COMPREHENSIVE FRAMEWORK PLANNING FOR RECONSTRUCTION AND DEVELOPMENT OF THE KURDISTAN REGION IRAQ}

\section{Development of a national livelihood program}

\section{II-Housing-cum livelihood strategy program}

The objectives of this program is two folded: 1- to provide an affordable and decent house for every family in Kurdistan region, especially in the country side, either privately built or state sponsored and 2 - activate the domestic market relating to labor, producing and marketing local building materials and manufacturing articles used in construction for houses.

Decent housing: is a structure with at least (a living room, 2 bed room, kitchen, toilet and a bath) provides with basic standards of health, privacy and security built with wide use of local building materials and adapted building technology.The further objectives of this program is to activities more private sector participation in housing construction and thus promoting the economic development on the building sector too. The program should have a regional-wide dimension as illustrated bellow. The strategies of financing of the decent house should follow low interest and longer period of repayments. A nearly such strategy is currently practices to provide families with a house in both rural and urban areas.

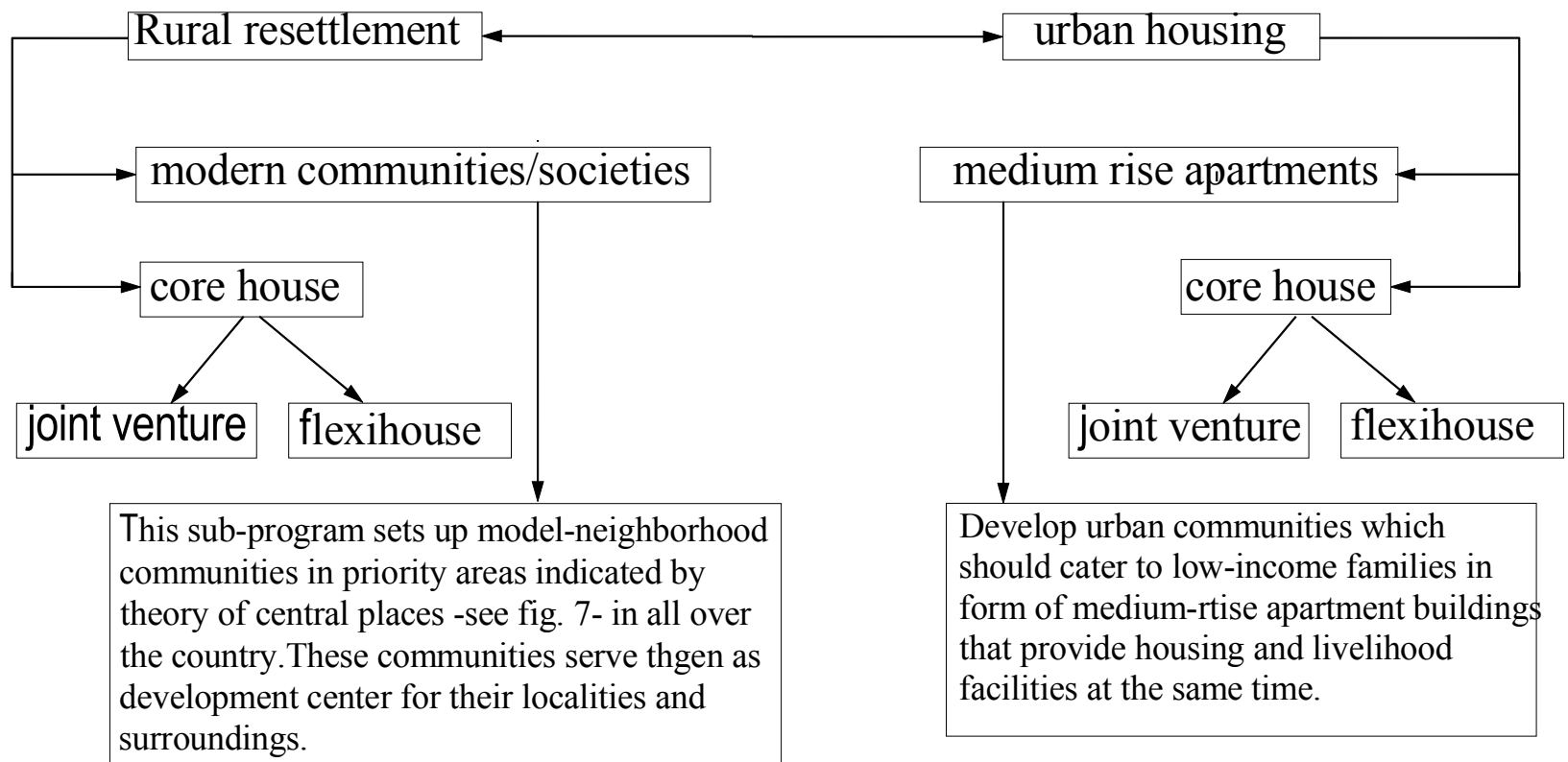

Fig.(8) A: Flow diagram showing Housing-cum-livelyhood strategy program.

(Source: Reasearcher) 


\section{A COMPREHENSIVE FRAMEWORK PLANNING FOR RECONSTRUCTION AND DEVELOPMENT OF THE KURDISTAN REGION IRAQ}

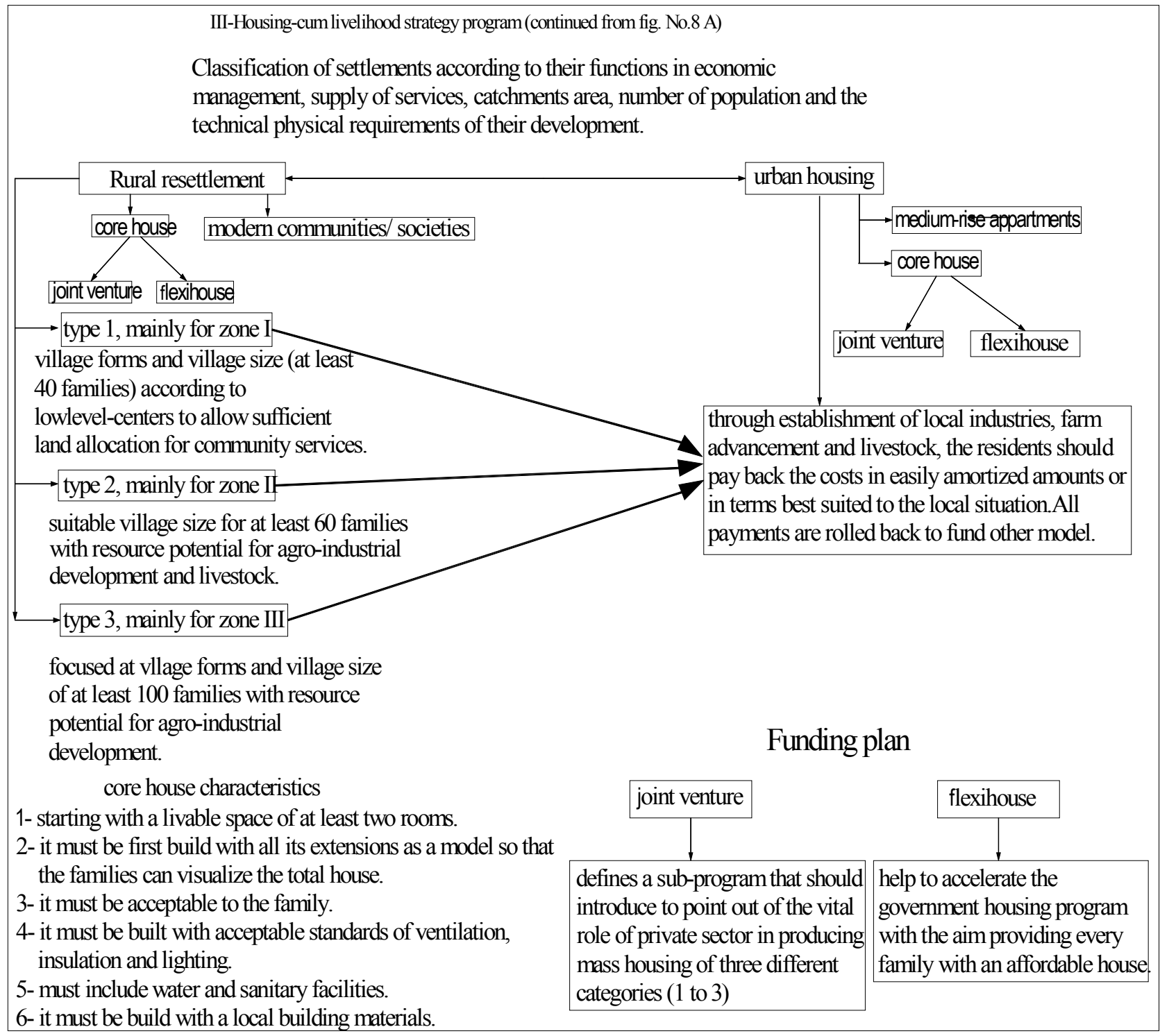

Fig. (8) B: Flow diagram showing Housing-cum-livelihood development program based on the geographical Regions. (Source: Researcher). 


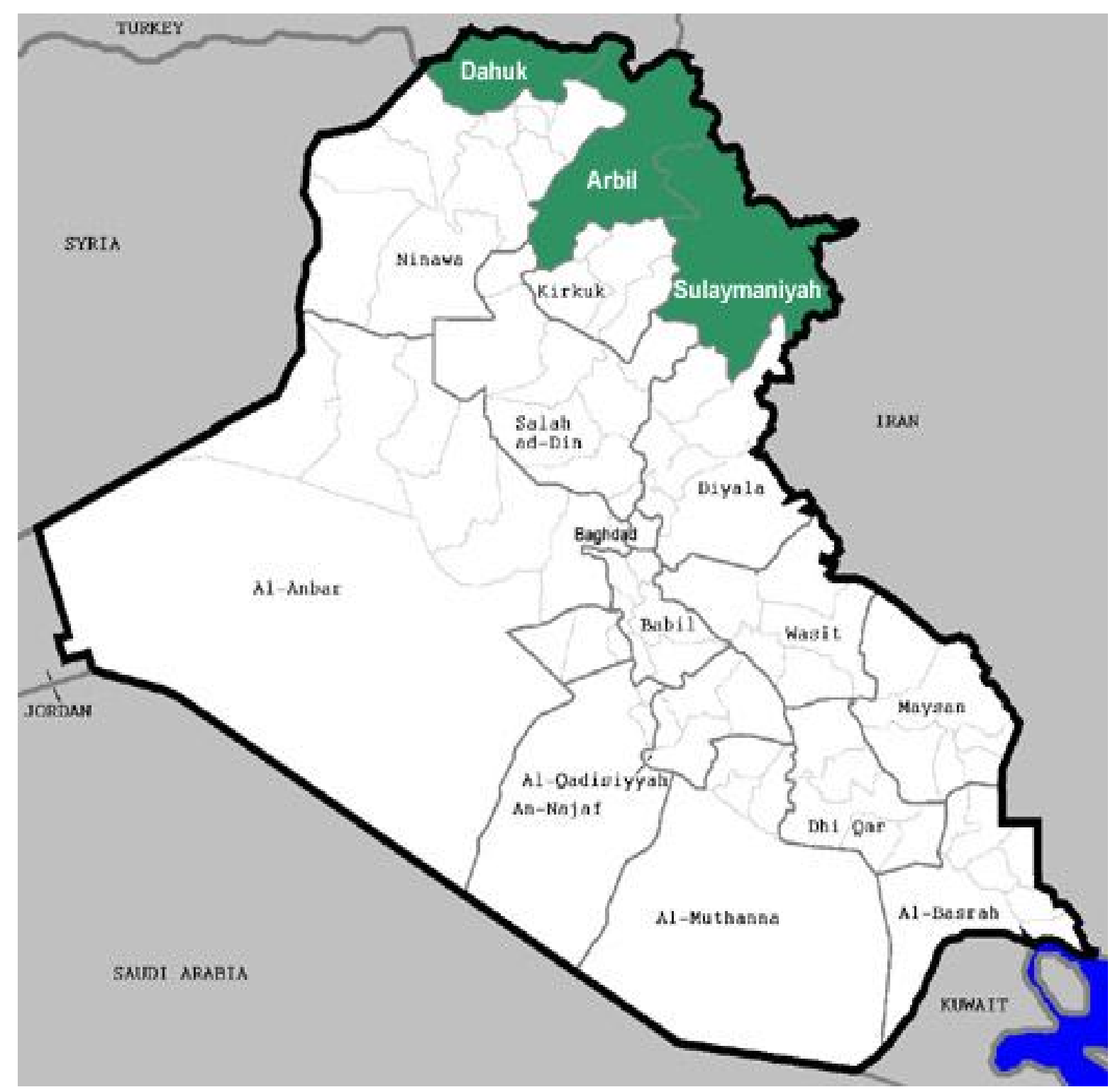




\title{
إطار التخطيط الثامل لإعادة بناء وتطوير مناطق كردستان العراق
}

\author{
عثمان كريم محمد \\ مدرس \\ الكلية التقنية - جامعة السليمانية
}

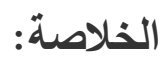

مفهوم الدراسة الحالية "اطر التخطيط الثامل" أمر بالغ الأهمية لكونة يشمل عددا من القضايا الهامة ذات

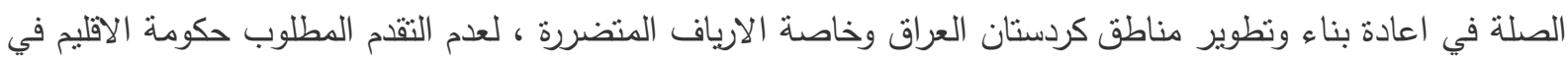

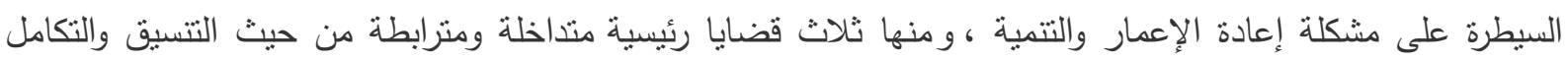

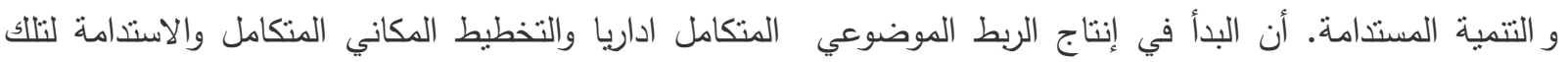

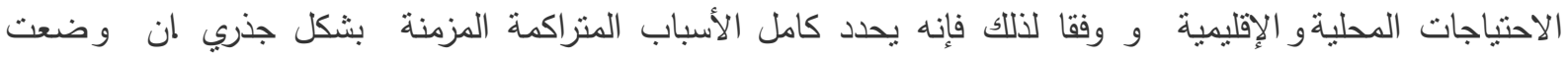
الحلول المناسبة في إطار "تخطبط العمل" للمشاكل في كل من المناطق الريفية والحضرية الذي تضمن دائرة منرابطة،

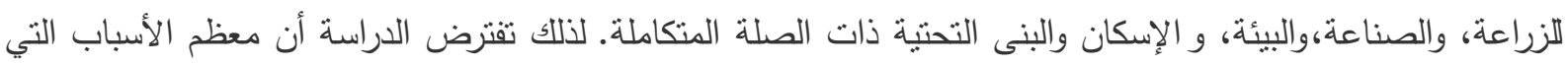
أدت إلى فثل الحكومات في المنطقة تكمن في عدم تشخيص المشكلة نفسها التي تؤدي الى تفكلى وتفريق وعدم ربط تخطيط الأعمال للمؤسسات التي نثارك بشكل مباشر أو غير مباشر في إعادة التأهيل والتتمية في المنطقة. بالإضافة إلى تُونى هذا، فإن المشكلة لا نزال تشهد مازال الخطأ السائد قائمالذى يعتبر ان التتمية هى التوفير فئرئر السكن فقط. 